\title{
Koncepcje federacyjne Milana Hodžy
}

\author{
The federal concepts of Milan Hodža
}

\author{
PIOTR EBERHARDT \\ Instytut Geografii i Przestrzennego Zagospodarowania im. S. Leszczyckiego PAN \\ 00-818 Warszawa, ul. Twarda 51/55; p.ebe @ pan.pl
}

\begin{abstract}
Zarys treści. Przedstawiono dokonania twórcze i konceptualne Milana Hodžy, wybitnego polityka i myśliciela słowackiego, działającego w pierwszej połowie XX w. na rzecz utworzenia a następnie umocnienia dualistycznego państwa czechosłowackiego. Był orędownikiem federacji narodów środkowoeuropejskich. Postulował utworzenie federacji państw położonych nad Dunajem, a następnie integrację polityczną państw usytuowanych między Bałtykiem, Morzem Czarnym i Adriatykiem. Koncepcje te zostały w artykule szczegółowo omówione i poddane ocenie.
\end{abstract}

Słowa kluczowe: Milan Hodža, federacjonizm, Europa Środkowa.

Motto:

„Hodža jest zarówno wybitnym Słowakiem, Czechosłowakiem, Środkowo-Europejczykiem, Paneuropejczykiem i kosmopolitą." R.N. Coudenhove-Kalergi ${ }^{1}$

\section{Wprowadzenie}

W trakcie politycznych przemian na świecie kształtowały się liczne związki federacyjne łączące ze sobą poszczególne państwa, narody lub autonomiczne prowincje. Funkcjonowały one przez dłuższy lub krótszy czas, zmierzając w kierunku unitarnych jednostek politycznych. Bywało również odwrotnie w utworzonych związkach federacyjnych nasilały się w miarę czasu procesy dezintegracyjne, doprowadzając często do kryzysu i powrotu do poprzedniego stanu. Zdarzało się, że związki między poszczególnymi krajami w wyniku niekorzystnych uwarunkowań zewnętrznych ulegały spektakularnemu rozpadowi

\footnotetext{
${ }^{1}$ R.N. Coudenhove-Kalergi był twórcą koncepcji Paneuropy i prekursorem idei zjednoczenia Europy (więcej zob. Eberhardt, 2007). W potocznym polskim rozumieniu pojęcie kosmopolity ma konotacje negatywne i pejoratywne, dla Coudenhove-Kalergiego oznaczało nobilitację i uznanie.
} 
lub unicestwieniu. ${ }^{2}$ Przykładem może być unia federacyjna w postaci I Rzeczpospolitej, łączącej Królestwo Polskie i Wielkie Księstwo Litewskie. Uległa likwidacji, pomimo zaawansowanych procesów unifikacyjnych. Przyczyną było nie tyle osłabienie wewnętrzne wspólnoty ponadnarodowej, ile militarna agresja sąsiadów. Podobnie dramatyczny los spotkał pod koniec XX w. Federację Jugosłowiańską. Istniały również federacyjne wspólnoty polityczne, które funkcjonowały sprawnie i skutecznie przez dłuższy okres osiągając sukcesy na polu kultury, nauki i sztuki. Przyczyny tych przemian były bardzo różne i są obiektem zainteresowania historyków, politologów i geografów.

\section{Zasady federalizmu}

Do wyjaśnienia istoty i funkcjonowania politycznych systemów federalnych używa się różnorodnych kryteriów klasyfikacyjnych. Można grupować państwa federalne na podstawie historii ich powstania, według pionowego rozkładu podziału władzy pomiędzy wspólnotą a jej częściami składowymi lub układu poziomego zachodzącego między poszczególnymi instytucjami federalnymi lub autonomicznymi prowincjami. Państwa federalne powstają w rezultacie procesów integracyjnych względnie decentralizacyjnych. W pierwszym przypadku mamy do czynienia ze zjednoczeniem dotychczas niezależnych państw, w drugim - z wykształceniem się samodzielnych struktur członkowskich w obrębie uprzednio bardziej scentralizowanej jednostki politycznej ${ }^{3}$.

Przyczyną powstania wielkich państw i mocarstw regionalnych lub światowych były często umowy federacyjne - wymuszone lub dobrowolne. Te ostatnie były bardziej trwałe, gdyż w większym stopniu spełniały interesy zainteresowanych partnerów. Równorzędność ich mogła być faktyczna (np. Stany Zjednoczone) lub iluzoryczna (np. ZSSR). Tworzenie, rozwój i rozkład związków federacyjnych był znamienną cechą rozwoju historycznego i drogą do powstania lub upadku wielkich imperiów. Obecnie na świecie mamy liczne

\footnotetext{
${ }^{2}$ Pierwsze formy quasi-federacji pojawiły się w starożytnej Grecji w postaci związku miast - państw (poleis). Można podać jako przykład Związek Delijski, będący federacją znacznej części państw helleńskich. W czasach bardziej współczesnych powstał amerykański model federalizmu, potwierdzony przez kongres konstytucyjny w Filadelfii (1776). Obszerne wyjaśnienie istoty państwa federalnego pochodzi od francuskiego filozofa i polityka Alexisa de Tocqueville’a, który w latach 1830. przedstawił królowi Ludwikowi Filipowi raport o funkcjonowaniu systemu federalnego Stanów Zjednoczonych. Problematyka ta później była rozważana od strony teoretycznej i politycznej. W polskiej współczesnej literaturze naukowej kwestie te są dość popularne (Suchecki, 1968; Federalizm..., 1998; Matusik, 2009).

${ }^{3} \mathrm{~W}$ naukowym i potocznym rozumieniu federacja jest traktowana jako rodzaj formy państwa. Federalizm natomiast jest systemem organizacji państwa, czyli podziału kompetencji i sposobu organizowania procesu decyzyjnego w ramach wspólnoty politycznej, polegającej na rozdzieleniu konstytucyjnych i urzędowych uprawnień pomiędzy władzę centralną a jej regionalne odpowiedniki, w ten sposób, że każda z nich odpowiada za wypełnianie określonych zadań przy wykorzystaniu uprawnień jej przysługujących. Jako system organizowania i sprawowania władzy federalizm jest formą podziału wspólnoty politycznej, w której istnieje zasada, że władza centralna i regionalna wykonuje przynależne jej uprawnienia przy zachowaniu politycznej autonomii, terytorialnej integralności i samodzielności.
} 
przykłady związków federacyjnych, które mają odzwierciedlenie w oficjalnej nazwie państwa (np. Federalna Republika Niemiec lub Federacja Rosyjska). Było w historii wiele typów i rodzajów państw federacyjnych o różnym stopniu spoistości. Funkcjonowały mniej lub bardziej skutecznie, odnosząc zarówno sukcesy, jak i porażki. Pod względem prawnym, wielkościowym, ekonomicznym czy militarnym są często ze sobą nieporównywalne, dlatego ich analiza i ocena natrafia na trudności formalne i merytoryczne. ${ }^{4}$

Tworzenie się w sprzyjających okolicznościach historycznych bytu federacyjnego było zawsze realizacją pewnej koncepcji lub wizji ideologicznej lub politycznej. W ostatecznym efekcie przyjmowała ona konkretną postać geograficzną na mapie świata. Wewnętrzny układ odznaczał się pewną policentrycznością i zróżnicowaniem wewnętrznym. Dzięki powstaniu układu federacyjnego pojawiały się jednostki polityczne o większej powierzchni oraz o poważniejszej sile ekonomicznej i militarnej. Pomimo że mogły być bardziej narażone na dezintegrację, to one stały u podstaw kształtowania się wielkich imperiów. Przesłanki tworzenia wspólnot federacyjnych były zgodne z sekularnymi tendencjami zmierzającymi do eliminacji małych tworów politycznych. Na tempo procesów unifikacyjnych, a następnie federacyjnych, wpływały uwarunkowania obiektywne i subiektywne. Głównym zadaniem było umocnienie siły politycznej państwa. Nadrzędny ośrodek dyspozycyjny nie był w stanie zapewnić skutecznego nadzoru. Alternatywą dla centralizacji był układ federacyjny. Władze centralne, aby zapewnić kontrolę, przekazywały składowym podmiotom federacji daleko idące kompetencje, domagając się w zamian lojalności. Tworzono taki system prawny, aby wszystkie części składowe federacji były zainteresowane trwałością związku federacyjnego. Zmierzano równocześnie do ograniczenia tendencji odśrodkowych, które mogły doprowadzić do osłabienia, a nawet rozpadu wspólnoty. ${ }^{5}$ Utworzone federacje obejmowały zazwyczaj terytorium zróżnicowane pod względem kulturowym i językowym. Odrębności te były zwykle respektowane. Wymagało to prowadzenia przez centrum polityki tolerancyjnej uwzględniającej interesy poszczególnych podmiotów federacji. Panowało przekonanie, że federalizm w formie demokratycznej i skutecznej

\footnotetext{
${ }^{4}$ Federalizm jest pojęciem obejmującym zagadnienia zarówno prawne, jak i polityczne. Jest równocześnie pewnym nurtem filozoficzno-ideologicznym nawiązującym do personalizmu. Podkreślenie w tym przypadku wymiaru osobowego oznacza zaprzeczenie zarówno kolektywizmowi, jak i indywidualizmowi. W takim ujęciu federalizm jest postrzegany jako pewien model organizacji społeczeństwa (Borkowski, 2006, s. 90).

${ }^{5} \mathrm{~W}$ literaturze przedmiotu federalizm jest traktowany jako model przeciwstawnych tendencji zmierzających do integracji lubi dezintegracji. Miedzy biegunami partykularyzmu i centralizmu pojawia się federalizm, rozumiany jako system gdzie zachodzi możliwie sprawiedliwa równowaga pomiędzy jednością a różnorodnością, integracją a rozdrobnieniem, całością a jej częściami składowymi. Partykularyzm, centralizm i federalizm funkcjonują jako „typy idealne” w koncepcji Maksa Webera. Z tego względu wg Kinsky'ego nie powinno się ujmować ustroju federalnego jako optymalnego sposobu na rozwiązywanie problemów społecznych, politycznych, gospodarczych czy kulturalnych. Federalizm jest najwyżej tym, co powiedział w odniesieniu do demokracji Winston Churchill - najgorszą z możliwych form ustrojowych, ale z wyłączeniem wszystkich możliwych (Kinsky, 1999, s. 44, 61).
} 
może istnieć tylko wtedy, gdy ustrój federacyjny opiera się na prawie do samostanowienia narodów wchodzących w skład jednolitego państwa, a same narody identyfikują się z federalistyczną jednością (Kinsky, 1999, s. 141).

W trakcie rozwoju historycznego pojawiło się wiele programów federacyjnych. Urzeczywistnione odegrały istotną rolę polityczną. Konstruowano również projekty, których nie udało się zrealizować. One także odegrały swoją rolę, i to nie tylko w wymiarze symbolicznym. Prawdopodobieństwo ich spełnienia było niejednakowe, niektóre z nich były bliskie realizacji, inne zaś od początku utopijne. Świadczyły jednak o krystalizowaniu się poglądów wśród elit przywódczych lub postaw świadomościowych znaczniejszych grup społecznych, zainteresowanych korzyściami płynącymi z integracji lub zmiany w konstelacji podległości. Potencjalna federacja miała zapewnić bezpieczeństwo i lepsze perspektywy rozwoju gospodarczego. Do takich głośnych programów federacyjnych, popularnych w ciągu całego XX wieku należały między innymi projekty połączenia związkiem federacyjnym państw i narodów położonych w Europie Środkowo-Wschodniej. Miał to być związek kilku lub kilkunastu państw usytuowanych miedzy Bałtykiem, Morzem Czarnym i Adriatykiem. Zamieszkałe tam narody, zagrożone przez Niemcy i Rosję (ZSRR) liczyły, że złączenie w układ federacyjny uratuje je przed potencjalną agresją i dominacją mocarstw niekryjących swych imperialnych ambicji.

Najbardziej aktywni w tej dziedzinie byli politycy i uczeni polscy. Przyczyną było stałe zagrożenie niemiecko-rosyjskie. Uważano, że poprzez polityczną konsolidację państw położonych na pomoście bałtycko-czarnomorskim uda się stworzyć poważną siłę geopolityczną, zdolną do zapewnienia bezpieczeństwa. Konstruowano projekty ciekawe konceptualnie, ale raczej nie do spełnienia. Cechowała je polonocentryczność i były krytycznie przyjmowane przez potencjalnych partnerów, którzy inaczej postrzegali rzeczywistość. Państwa Europy Środkowo-Wschodniej dzieliły liczne sprzeczności, brakowało wzajemnego zaufania, a wyznaczone granice między nimi były obiektem sporów i konfliktów. Zakładano z nadmiernym optymizmem, że w ramach wspólnoty uda się je pozytywnie rozwiązać. Było to założenie w zasadzie z góry skazane na niepowodzenie, mimo to powstawały plany i koncepcje zmierzające do zmniejszenia roli wewnętrznych rozgraniczeń i powołania związku federacyjnego. Do bardziej znanych można zaliczyć polską koncepcję tzw. Międzymorza, czyli wspólnoty państw położonych między Bałtykiem a Morzem Czarnym (Grygajtis, 2001). Wymagała maksymalnego osłabienia ZSRR, poprzez jego dezintegrację terytorialną. W myśl tej idei, która przyjęła nazwę ruchu prometejskiego, działano na rzecz wyzwolenia ludów i narodów imperium sowieckiego (Mikulicz, 1971). Starano się również działać w kierunku poprawy stosunków między poszczególnymi narodami tej części Europy. Zadaniem nadrzędnym było utworzenie w przyszłości rozległej wspólnoty ponad podziałami państwowymi, narodowymi i religijnymi. 
Wielu polskich uczonych i działaczy politycznych, których interesowały zagadnienia geograficzne i geopolityczne starało się rozwiązać ten trudny problem. ${ }^{6}$ Liczne programy z tego zakresu powstawały w XIX wieku, w okresie międzywojennym, następnie w latach II wojny światowej. ${ }^{7} \mathrm{~W}$ rezultacie opanowania tego całego obszaru przez Związek Sowiecki utraciły one aktualność. Niemniej pod zwierzchnictwem Moskwy ukształtowała się wspólnota państw socjalistycznych, która była niewątpliwie rodzajem federacji. Dopiero po rozpadzie imperium sowieckiego państwa Europy Środkowej uzyskały podmiotowość polityczną i dawne koncepcje zjednoczeniowe mogły stać się inspiracją do nowych działań zmierzających do współpracy i jedności. Zdano sobie równocześnie sprawę, że kwestia federacji państw środkowoeuropejskich w kontekście rozszerzania się Unii Europejskiej przyjęła inną postać ideową, terytorialną i geopolityczną. Nawiązywanie do dawnych koncepcji, a zwłaszcza prezentowanie ich kreatorów i animatorów niesie jednak istotną wartość poznawczą i symboliczną.

W odróżnieniu od wizjonerów polskich, którzy stali się obiektem dyskursu naukowego, wiedza w Polsce o dokonaniach badaczy pochodzących z innych krajów Europy Środkowej jest znikoma. Działaczem politycznym o dużym formacie politycznym, głoszącym oryginalny i spójny program, którego celem ostatecznym miała być federacja państw położonych między Rosją a Niemcami, był Milan Hodža. Ten wybitny słowacki działacz polityczny i uczony jest w naszym kraju mało znany. Przypomnienie jego drogi życiowej, poglądów i dokonań twórczych może być przesłanką do szerszych badań nad rozwojem europejskiej myśli geopolitycznej, w tym nad programami zmierzającymi do integracji polityczno-kulturowej państw środkowoeuropejskich.

\section{Milan Hodža - życie i działalność}

Milan Hodža urodził się 1 lutego 1878 r. w rodzinie rdzennie słowackiej w Sučanach na Słowacji ${ }^{8}$. Był synem Ondreja Hodžy, pastora miejscowej

\footnotetext{
${ }^{6}$ Między innymi Bogumił Jastrzębowski, Ks. Adam Czartoryski, Stefan Buszczyński oraz w późniejszym czasie Karol Stojanowski, Roman Knoll (Lucjan Bielski), Jan Wolski i Aleksander Bergman (Wolański, 1998; Grabowiec, 1998; Grygajtis, 2001; Eberhardt, 2010).

${ }^{7}$ Koncepcja wielonarodowej federacji położonej w tej części Europy była bliska Marszałkowi Józefowi Piłsudskiemu. Zamierzał połączyć w luźnym związku federacyjnym Polskę, Ukrainę, Białoruś i Litwę. W późniejszym czasie w latach II wojny światowej daleko zaawansowane projekty zjednoczeniowe przegotowywali premier polskiego rządu emigracyjnego Władysław Sikorski i prezydent Czechosłowacji Edward Benesz. Oprócz polityków tą kwestią zajmowali się także naukowcy, tworząc różnorodne wizje zjednoczenia narodów i krajów Europy Środkowej.

${ }^{8}$ Twórczość oraz światopogląd ideowo-polityczny Hodžy były obiektem zainteresowania i analiz licznych słowackich historyków i geografów. Pierwsze prace poświęcone jego poglądom i działalności pojawiły się już w okresie międzywojennym (Votočkova-Lauermannová, 1938). Po wojnie o Hodžy niewiele pisano, dopiero po upadku komunizmu i uzyskaniu przez Słowację pełnej niepodległości pojawiły się opracowania poświęcone temu wybitnemu politykowi i uczonemu (Juriček, 1994; Lukàč, 1997; Cambel, 2001; Tauchen, 2009). Ukazało się również opracowanie zbiorowe pod redakcją M. Peknika (2006), które zawiera kilkanaście artykułów dotyczących jego dokonań twórczych.
} 
parafii luterańskiej i Klementyny z domu Plechovej. Uczęszczał do gimnazjum w Bańskiej Bystrzycy, w Sopronie i w siedmiogrodzkim Sibiu (węg. Nagyszben), gdzie w 1894 r. uzyskał świadectwo maturalne. Studiował prawo w Budapeszcie i w Kluż (1896-1900), a następnie filozofię w Wiedniu, gdzie uzyskał w 1918 r. doktorat oraz w 1921, pomimo braku habilitacji, stanowisko profesorskie. Był wszechstronnie wykształconym erudytą, władał biegle dziewięcioma językami (słowackim, czeskim, węgierskim, niemieckim, polskim, angielskim, francuskim, rumuńskim i serbochorwackim). Jako młody

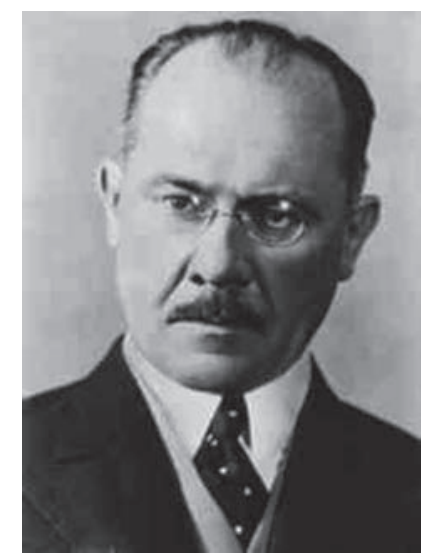

Milan Hodža

człowiek zajmował się dziennikarstwem. Założył gazetę codzienną w języku słowackim Slovenský dennik, a następnie był redaktorem pisma Slovenský týždennik (1903-1914). Dzięki popularności u wyborców został powołany w 1905 r. do parlamentu węgierskiego. Nawiązał wówczas jako poseł bliskie kontakty z elitą polityczną ówczesnych Austro-Węgier, w tym z dworem wiedeńskim. Na forum publicznym wysuwał propozycje reformy administracyjno-prawnej Cesarstwa Austro-Węgierskiego, w kierunku podziału państwa na narodowe prowincje autonomiczne. Współpracował w tym zakresie z Franciszkiem Ferdynandem d'Este, potencjalnym następcą tronu, późniejszą ofiarą zamachu w Sarajewie. Prace te miały na celu zlikwidowanie istniejącego dualizmu Cesarstwa i federalizację monarchii Habsburgów. Miało to polegać na utworzeniu kilkunastu prowincji narodowych o dużych uprawnieniach podmiotowych. Równocześnie Hodža starał się być orędownikiem interesów narodu słowackiego. Wstąpił do Słowackiej Partii Narodowej, w której pełnił funkcję wiceprzewodniczącego. W okresie I wojny światowej przebywał głównie w Wiedniu, działając wśród intelektualistów słowackich i czeskich. 
W chwili rozpadu Cesarstwa Austro-Węgierskiego uczestniczył w redagowaniu historycznej deklaracji „martinowskiej”, która przygotowywała utworzenie państwa czechosłowackiego, mającego być związkiem federacyjnym Czech i Słowacji. Zakładał, że jest to optymalne rozwiązanie dla przyszłych losów Słowacji. Był przeciwnikiem wizji niepodległego państwa słowackiego, które w jego opinii nie miało szans oderwania się od Węgier i samodzielnej egzystencji. Szybko zaczął odgrywać istotną rolę we władzach federalnego państwa. Należał do grona najwybitniejszych mężów stanu Republiki Czechosłowackiej. Pełnił wielokrotnie funkcje ministerialne, w tym ministra unifikacji prawa, rolnictwa, szkolnictwa i spraw zagranicznych. Jako jedyny Słowak stanął na czele rządu Republiki (1935-1938), a przez kilka dni pełnił nawet funkcję prezydenta Republiki Czechosłowackiej (grudzień 1935). W okresie międzywojennym był profesorem i wykładowcą historii współczesnej na Uniwersytecie w Bratysławie oraz aktywnie działał na polu nauki i publicystyki.

Pasjonował się głównie problematyką federalizmu - w przekonaniu, że małe państwa tracą rację bytu. Wychodząc z tego pragmatycznego założenia stał się prekursorem wielu projektów zmierzających do jedności politycznej państw środkowoeuropejskich. Przewidywał trafnie, że nazistowskie Niemcy i bolszewicka Rosja mają w planie podporządkowanie krajów Środkowej Europy. Do obu tych mocarstw podchodził nieufnie; to go różniło od współczesnych mu polityków czeskich i słowackich, którzy nie dostrzegali potencjalnego niebezpieczeństwa ze strony wschodniego mocarstwa. Twierdził, że tylko wspólny front państw położonych „między Gdańskiem a Salonikami” jest w stanie uratować te państwa przed zbliżającą się katastrofą geopolityczną

Punktem przełomowym w karierze politycznej Hodžy była Konferencja Monachijska i jej końcowy rezultat - czyli unicestwienie państwa, które z takim zaangażowaniem współtworzył. Było to dla niego tym bardziej bolesne, że rząd, któremu przewodził był zmuszony pod presją wielkich mocarstw zaakceptować werdykt. Nie mogąc się z nim pogodzić Hodža wyjechał do Szwajcarii, a następnie do Francji. Przewodniczył Słowackiej Radzie Narodowej w Paryżu (1939-1940). Nie zaakceptował utworzonego marionetkowego „niepodległego” państwa słowackiego. Stał pryncypialnie na stanowisku przywrócenia po wojnie Republiki Czechosłowackiej, która miała być wspólnym państwem dwóch pełnoprawnych narodów.

Po klęsce Francji Hodža udał się do Wielkiej Brytanii, gdzie pełnił funkcję członka Rady Państwa w emigracyjnym rządzie Czechosłowacji, formalnie uznanym przez sojuszników zachodnich oraz przez ZSRR. Hodža traktował to jako gwarancję likwidacji postanowień monachijskich. Z upływem czasu wycofał się z aktywnej działalności politycznej na rzecz pracy twórczej związanej z precyzowaniem koncepcji federacyjnych państw środkowoeuropejskich. W 1942 r. wydał w Londynie książkę pt. Federation in Central Europe. W końcu opuścił Wielką Brytanię i dotarł do Stanów Zjednoczonych; uzyskał 
tu habilitację i został profesorem na Uniwersytecie w Yale. Zmarł 27 czerwca 1944 r. w miejscowości Clearwater w Kalifornii, a pochowany został w Chicago. W 2002 r. dokładnie w rocznicę śmierci jego szczątki zostały uroczyście złożone na cmentarzu narodowym w Martinie.

\section{Federacja Czech i Słowacji}

Przez całe życie Hodža dążył do zapewnienia narodowi słowackiemu optymalnych warunków do utrzymania i kultywowania odrębności etnicznej. Zdawał sobie sprawę z nierealności uzyskania pełnej podmiotowości politycznej Słowacji, dlatego jego program w tym zakresie był dość ograniczony. Konstruował go na przesłankach pragmatycznych, a nie romantycznych. Dostrzegał uwarunkowania zewnętrzne oraz słabość demograficzną i organizacyjną narodu słowackiego. Wierny był spuściźnie twórców odrodzenia narodu słowackiego, którzy domagali się jedynie szerokiej autonomii i zapewnienia wolności w sferze językowo-kulturowej. Nie było tradycji własnej, słowackiej państwowości, do której można było nawiązać. Słowacy nie byli narodem historycznym. Symbolicznie wywodzili swoje dzieje od państwa wielkomorawskiego, ale był to właściwie mit pozbawiony wymowy politycznej. Należeli przez tysiąc lat do Korony Węgierskiej i zawsze byli przez nią traktowani jako mieszkańcy Górnych Węgier narodowości węgierskiej, posługujący się w życiu codziennym językiem słowiańskim. Propagatorzy odrodzenia narodu słowackiego, którzy działali w XIX w. obawiając się totalnej madziaryzacji występowali tylko w obronie zagrożonej identyfikacji etnicznej, głównie zaś - na rzecz zachowania w życiu publicznym języka słowackiego ${ }^{9}$.

Wychodząc z realistycznych przesłanek Hodža nie domagał się niepodległości i uzyskania przez Słowację podmiotowości politycznej. Aż do końca I wojny światowej uważał, że do federalizacji Ziem Korony Św. Stefana oraz uzyskanie ograniczonej autonomii terytorialnej należy zmierzać powolną drogą pertraktacji z władzami Budapesztu i Wiednia. Liczył, że w ramach potencjalnej reorganizacji Cesarstwa Austro-Węgierskiego może pojawić się kwestia słowacka i niektóre z jego dezyderatów zostaną spełnione. Przedłużająca się wojna i niepowodzenia na frontach, które doprowadziły do kryzysu politycznego monarchii Habsburgów zaktywizowały działalność działaczy słowackich.

\footnotetext{
${ }^{9}$ Literatura poświęcona dziejom słowackim jest obszerna. Można przykładowo wymienić książkę o charakterze monograficzno-przeglądowym opublikowaną w języku polskim (Kościelak, 2010) oraz opracowania popularne w języku słowackim (Špiesz, 1992; Durica, 2003). Bardziej problemowe ujęcia budzenia się słowackiego ruchu narodowego zawiera książka A. Gizy (2000). Poglądy wybitnych Słowaków odniesione do przeszłości, współczesności i przyszłości Słowacji zaprezentowano w interesującej pracy zbiorowej pod redakcją R. Chmela (Kwestia stowacka..., 2002). Klasyczną pozycją w języku angielskim o sytuacji Słowacji i Słowaków w ramach państwa czechosłowackiego jest dzieło O.V. Johnsona (1985), a o stosunkach węgiersko-słowackich - opracowanie E. Bakkera (1997). W przytoczonych opracowaniach można znaleźć bogatą bibliografię polsko-, słowacko- i anglojęzyczną.
} 
W ramach tej akcji Hodža nawiązał ścisłe kontakty z przedstawicielami narodów ciemiężonych przez władze węgierskie i austriackie. Biegła znajomość języków ułatwiła kontakty z Czechami, Polakami, Serbami, Chorwatami i Rumunami. Zakładał, że wspólny front zmusi Budapeszt i Wiedeń do liberalizacji systemu i doprowadzi do rozwiązań o charakterze federacyjnym.

Klęska Państw Centralnych i zbliżający się rozpad wielonarodowościowego Cesarstwa Austro-Węgierskiego wymagały od reprezentantów narodu słowackiego, w tym osobiście Hodžy, zajęcia odpowiedniego stanowiska i wybrania optymalnej opcji politycznej. Zdecydowanym przeciwnikiem byli Węgrzy, którzy w początkowej fazie wojny zlikwidowali słowackie instytucje kulturalno-oświatowe, a jedynym sojusznikiem reprezentanci narodu czeskiego. Od początku swej działalności Hodža był zwolennikiem współpracy, a następnie bliskiej wspólnoty z narodem czeskim. W miarę zbliżania się do końca wojny ta orientacja polityczna stawała się coraz bardziej popularna. Pierwsze kroki w kierunku jedności były podjęte w Stanach Zjednoczonych wśród emigrantów czeskich i słowackich, którzy rozpoczęli akcję na rzecz utworzenia niepodległego państwa czechosłowackiego. ${ }^{10}$

Było już wiadomo, że zbliża się okres przełomowy. W odróżnieniu jednak od emigracyjnych polityków Hodža dłużej wierzył w integralność Królestwa Węgier i pomimo trudności usiłował uzyskać od Budapesztu akceptację przyszłej autonomii Słowacji. W sytuacji kryzysowej politycy węgierscy byli bardziej skłonni do kompromisu i obiecywali duże uprawnienia samorządowo-kulturowe. Wydarzenia polityczne zdezaktualizowały projekty porozumienia węgiersko-słowackiego.

Politycy słowaccy przebywający w kraju, do których z opóźnieniem dołączył Hodža, stanęli na stanowisku powołania federacji czesko-słowackiej. Decyzje te zostały podjęte w maju 1918 r. przez czołowych polityków slowackich: Vavro Šrobara i Andreja Hlinkę. Niezależnie od tego w tymże miesiącu w amerykańskim Pittsburgu podpisano umowę między przedstawicielami Czeskiej i Slowackiej Rady Narodowej postulującej powstanie w najbliższym czasie niepodległego państwa czechosłowackiego ${ }^{11}$. Układ federacyjny dwóch narodów został zatwierdzony przez Słowacką Radę Narodową na posiedzeniu 30 października 1918 r. w miejscowości Turčianský Sv. Martin (dzisiaj: Martin).

\footnotetext{
${ }^{10}$ Na terytorium Stanów Zjednoczonych istniała liczna i dobrze zorganizowana diaspora słowacka i czeska. Działająca tam Liga Słowacka wraz z Czeskim Stowarzyszeniem Narodowym opublikowała w 1915 r. dokument programowy o konieczności utworzenia pełnoprawnego związku federacyjnego Czechów i Słowaków w jednym państwie (tzw. Umowa Clevelandzka). Niewiele później, w 1916 r. reprezentujący stronę czeską Tomasz Masaryk i przedstawiciel Słowaków Milan Ratisław Štefánik utworzyli Czecho-Słowacką Radę Narodową.

11 Akt proklamujący powstanie niepodległego państwa czechosłowackiego został formalnie uznany przez Francję 29 czerwca 1918 r., przez Wielką Brytanię - 9 sierpnia 1918 r. oraz przez Stany Zjednoczone - 3 września 1918 r.
} 
Po ostatecznej klęsce Państw Centralnych na gruzach monarchii Habsburgów powstała suwerenna Republika, będąca związkiem federacyjnym dwóch słowiańskich narodów: Czechów i Słowaków. Został uwieńczony pełnym sukcesem program polityków czeskich, głównie Masaryka. Działania polityków słowackich miały mniejsze znaczenie, ale bez ich udziału i determinacji unia obu narodów nie byłaby możliwa. Po formalnym powstaniu dualistycznego państwa rozpoczęły się dyskusje o rodzaju federacji i kompetencjach partnerów. Hodža wziął w nich aktywny udział, kategorycznie występując przeciwko używaniu pojęcia narodu czechosłowackiego. Głosił pogląd o istnieniu całkowicie odrębnych dwóch narodów, które kierując się względami politycznymi wybrały drogę federacyjną i tworzą jeden naród państwowy, a nie etniczny. Na forum publicznym występował w tej sprawie wielokrotnie, zajmując pryncypialne stanowisko. Dotyczyło to nawet nazwy państwa: (Czecho-Słowacja czy Czechosłowacja) - w tej kwestii jego usiłowania zakończyły się niepowodzeniem i konstytucja uchwalona w 1920 r. przyjęła nazwę jednoczłonową. W ciągu całego okresu międzywojennego Hodža był orędownikiem wspólnego państwa federacyjnego, ale występował na posiedzeniach rządu i parlamentu w obronie słabszego narodu. Podkreślał natomiast konieczność utrzymania jedności i wspólnoty państwowej. ${ }^{12}$

Postawa Hodžy była obiektem krytyki ze strony nacjonalistycznie nastawionych polityków słowackich. Sprzyjała im często ekstremistyczna polityka niektórych działaczy czeskich, którzy nie dostrzegali podmiotowości narodu słowackiego. Międzywojenna Czechosłowacja była bez wątpienia państwem demokratycznym, jednak tendencje unitarne miały licznych zwolenników wśród praskiego establishmentu. Było to dostrzegane na Słowacji i powszechnie panowała opinia, że idea państwa czechosłowackiego została zawłaszczona przez elitę czeską. Powodowało to wzajemne oskarżenia o separatyzm lub o nielojalność. Hodža domagał się pełnych praw dla ludności słowackiej, ale jednocześnie zwalczał przejawy nacjonalizmu słowackiego. W konsekwencji znalazł się w konflikcie ideowym ze swoimi dawnymi przyjaciółmi, którzy stopniowo zaczęli zajmować pozycje antyczeskie, a po decyzjach monachijskich stanęli na stanowisku budowy zmniejszonej terytorialnie, podporządkowanej hitlerowskim Niemcom, ale formalnie niepodległej Słowacji. Źródłem tej postawy był osobisty stosunek Hodžy do szowinizmu słowackiego: wszelkie jego przejawy piętnował jako objawy „ślepoty”, „kroku wstecz” i karykaturalnego rozwoju świadomości narodowej (Lukàč, 1997, s. 23). Do koncepcji

\footnotetext{
12 Pogląd na kwestię pozycji międzynarodowej Słowacji i jej stosunek do układu federacyjnego z Czechami przedstawił Hodža w tekście opublikowanym w 1934 r. pod tytułem, który w zasadzie tłumaczy jego stanowisko: Nie centralizm, nie autonomizm, ale regionalizm $w$ jednolitym narodzie politycznym. Wypowiada się tam zdecydowanie przeciw suwerenności, względnie pełnej autonomii Słowacji. Broni tezy o bezwarunkowej jedności czechosłowackiego narodu politycznego. Twierdzi że radykalne odrzucenie żądań separatystycznych leży w interesie Słowacji, gdyż: „bez Czechosłowacji i bez czechosłowackiej jedności politycznej nie byłoby też Słowacji” (Hodža, 2002a, s. 188).
} 
czechosłowakizmu Hodža podchodził dość niejednoznacznie. Jako zwolennik federalizmu potępiał separatyzm słowacki, z drugiej zaś strony, będąc orędownikiem wspólnoty państwowej był przeciwnikiem zlania się w sensie kulturowym dwóch narodów w jeden etniczny naród czechosłowacki. ${ }^{13}$

Podczas II wojny światowej, pomimo że odsunięty przez ekipę Benesza od bieżących spraw państwowych, nadal optował za jednolitym państwem czechosłowackim. Negatywnie odnosił się do posunięć ówczesnego marionetkowego rządu słowackiego, który głosił hasła nacjonalistyczne, antysemickie, antyczeskie i autorytarne. Był przekonany o ich tymczasowości, nonsensowności, a także o zbrodniczym charakterze państwa kierowanego przez ekipę ks. Józefa Tiso. ${ }^{14}$

\section{Federacja Dunajska}

Prawie do samego końca I wojny światowej Hodža był zwolennikiem federalizacji Cesarstwa Austro-Węgierskiego. Sądził, że optymalnym rozwiązaniem byłby podział dualistycznej monarchii na autonomiczne prowincje, wśród których byłaby Słowacja. W odróżnieniu od innych polityków nie uważał, że państwo to jest skazane na likwidacje. Cesarstwo pomimo rozczłonkowania etnicznego stanowiło zwartą jednostkę geograficzną zintegrowaną wzdłuż wielkiego szlaku wodnego, jakim był Dunaj. Do sprawnego funkcjonowania wymagało jedynie reorganizacji ustrojowej i terytorialnej. Konieczność poważnych zmian była dostrzegana w Wiedniu i sprzyjało im wielu eksponowanych polityków austriackich. Sprawa była trudna do przeprowadzenia, gdyż strona węgierska była przeciwna koncepcjom federacyjnym w obawie, że prowincja węgierska będzie jedną z wielu. Dopiero w ostatniej fazie wojny, jak wspomniano, władze w Budapeszcie zaczęły rozważać możliwość pewnej decentralizacji Królestwa

\footnotetext{
13 Świadczy o tym oryginalna wypowiedź z cytowanego już artykułu z 1934 r.: „Słowacja może istnieć tylko w związku z historycznymi ziemiami czeskimi, ale także na ziemie czeskie musi przeniknąć pogląd, że i one potrzebują Słowacji. Nie wystarczy nam braterstwo uczuć: trzeba wesprzeć naszą jedność obopólnym zainteresowaniem, a przede wszystkim uznaniem tego, że jedność leży w interesie zarówno Słowaków, jak i Czechów (...) uznanie znaczenia Słowacji dla państwa może spowodować, że Słowacja pod względem zarówno politycznym jak i gospodarczym znajdzie swoje miejsce w politycznym narodzie czechosłowackim oraz że we własnym interesie odrzuci każdą próbę separacji politycznej. Tak ukierunkowana polityka państwa na pewno doprowadzi do wewnętrznej konsolidacji narodowej, w której przejściowe dążenie do autonomizmu politycznego stanie się bezprzedmiotowe. Sam autonomizm nie może polegać ani na negacji, ani na absencji: co jest w nim czyste i prawdziwe, niech zostanie zrealizowane w pozytywnej polityce wspólnego państwa” (Hodža, 2002a, s. 187-188). Tezę tę wyraził jednoznacznie: „Słowacy i Czesi są na siebie skazani, dlatego należy dać wspólnocie czechosłowackiej mocne podstawy przez usunięcie nieporozumień stojących Słowakom i Czechom na drodze .... My potrzebujemy Czechów, ale oni też nas potrzebują” (Hodža, 2002b, s. 161, 163).

14 Józef (Jozef) Tiso, słowacki ksiądz katolicki, lider słowackiej Partii Ludowej. Wykorzystując dyktat Układu Monachijskiego stanął na cele autonomicznego rządu słowackiego. pełnił w latach 19391945 funkcję prezydenta Republiki Słowackiej, państwa całkowicie podporządkowanego III Rzeszy Niemieckiej. Wprowadził sądy autorytarne. Był współodpowiedzialny za deportację słowackich Żydów do obozów zagłady. Po wojnie skazany na karę śmierci i stracony 18 kwietnia 1947 r. w Bratysławie.
} 
Węgierskiego. Hodžę traktowano jak poważnego partnera reprezentującego interesy słowackie. Klęska Państw Centralnych zniweczyła te nieudolne próby federalizacji państwa zmierzającego do katastrofy geopolitycznej. W diametralnie odmienionej sytuacji Hodža zmienił swoją orientację polityczną - stał się już do końca życia orędownikiem federacji czesko-słowackiej.

Utworzona Republika Czechosłowacka była państwem terytorialnie i etnicznie niejednolitym, z niekorzystną konfiguracją granic politycznych. W dodatku ze wszystkimi sąsiadami miała nieprzyjazne relacje. Ze względu na liczną mniejszość niemiecką (3,5 mln obywateli) stosunki z Niemcami i Austrią były napięte i groziły utratą rejonów przygranicznych, zatarg o Śląsk Cieszyński uniemożliwił bliższą współpracę z Polską, a przyłączenie do Słowacji etnicznych obszarów węgierskich groziło odwetem militarnym ze strony Budapesztu. Broniąc się przed rewanżyzmem węgierskim powstała pod kuratelą Francji tzw. Mała Ententa, czyli sojusz Czechosłowacji, Rumunii oraz Królestwa Serbów, Chorwatów i Słoweńców (późniejszej Jugosławii). Dla konsekwentnego federalisty stan ten wymagał dalszych działań unifikacyjnych (Tauchen, 2009, s. 455).

W związku z tym Hodža wysunął propozycję utworzenia federacji państw dunajskich. ${ }^{15}$ Przypominał, że pomimo wielu wadliwie rozwiązywanych kwestii ustrojowo-narodowościowych przez stulecia istniał zintegrowany układ geopolityczny pod władzą dynastii Habsburgów. Dopasowały się do niego powiązania gospodarcze oraz system komunikacyjny. Po wojnie i zmianie granic zostało to zniweczone. Działały narodowe partykularyzmy zamykające się przed wszelkimi koncepcjami uniwersalistycznymi, a gospodarka była zmuszona funkcjonować na ograniczonych terytorialnie rynkach krajowych. Hodža twierdził, że dla wszystkich państw tego regionu będzie korzystne odtworzenie jedności ekonomicznej już na nowych zasadach prawno-ustrojowych. Niewielkie państwa położone nad Dunajem powinny dążyć do wspólnoty ponad występującymi podziałami politycznymi i etnicznymi. Zaliczał do nich: Czechosłowację, Austrię, Węgry, Jugosławię, Rumunię i Bułgarię (Tauchen, 2009, s. 451). Potrzebę powstania dużej ponad narodowej federacji uzasadniał za pomocą argumentów historycznych, ekonomicznych i w końcu geopolitycznych. Dorzecze Dunaju stanowi jedność gospodarczą połączoną dogodnym i tanim transportem rzecznym. Stolice większości tych krajów leżą bezpośrednio nad Dunajem (Wiedeń, Budapeszt) lub w jego pobliżu (Bukareszt, Belgrad). Stolica Słowacji Bratysława też położona jest przy tym szlaku wodnym. Uwypuklał ten czynnik geograficzno-hydrologiczny twierdząc, ze gdyby nie było federacji czechosłowackiej, to ziemie czeskie byłyby odcięte od Dunaju i skazane na istnienie w strefie niemieckiej.

\footnotetext{
${ }^{15}$ Konieczność utworzenia federacji państw usytuowanych nad Dunajem Hodža uzasadniał w publikacjach publicystycznych ukazujących się głównie na przełomie lat 1930., gdy Mała Ententa przeżywała wyraźny kryzys polityczny, a na Węgrzech nasilały się żądania rewizji granic.
} 
Ważniejsze od oczywistych korzyści gospodarczych były jednak przesłanki polityczne. Hodža wielokrotnie dowodził, że przyszedł kres małych państw nad Dunajem i jedynym ratunkiem dla nich może być układ federacyjny ${ }^{16}$. Oprócz Niemiec i ZSSR (Rosji) obawiał się rewizjonizmu węgierskiego. Przewidywał, że Węgrzy nigdy nie zrezygnują z południowej Słowacji, Siedmiogrodu i Wojwodiny. To musi doprowadzić do destabilizacji wewnętrznej i lokalnych konfliktów militarnych. Zagraża to wszystkim państwom położonym nad Dunajem, a w konsekwencji może doprowadzić do obalenia porządku wersalskiego. Wyjściem z sytuacji jest zatarcie rozgraniczeń politycznych między wymienionymi sześcioma państwami. Gdy granice między członkami federacji będą miały charakter symboliczny, to nie będą one obiektem konfrontacji i stracą swój charakter konfliktogenny. Państwo węgierskie jako pełnoprawny i równorzędny partner dużej federacji inaczej będzie postrzegało upokarzające i niezmiernie bolesne decyzje podjęte przez zwycięskie mocarstwa zachodnie na konferencji w Trianon (Tauchen, 2009, s. 455).

Przy propagowaniu wizji federacji dunajskiej Hodža podkreślał wyjątkową rolę Słowacji jako kraju usytuowanego w strategicznym miejscu, na przecięciu połączeń tranzytowych między północą i południem oraz wschodem i zachodem. Ze względu na to położenie tylko Słowacja może być zwornikiem wszelkich zamierzeń integracyjnych ${ }^{17}$.

Propozycja federalizacji państw dunajskich była koncepcją rewolucyjną, toteż nie została przychylnie przyjęta. Ówczesne warunki geopolityczne nie sprzyjały tego typu humanistycznym i pacyfistycznym wizjom. Zbliżała się wielka konfrontacja militarna, a państwa położone nad Dunajem miały być ofiarą polityki aneksyjnej wielkich mocarstw. Ponadto państwa dunajskie były do siebie nastawione nieufnie, a w zasadzie wrogo. Republika Czechosłowacka była państwem dobrze prosperującym i sprawnie zorganizowanym, jednak nie była tak postrzegana przez sąsiadów, którzy traktowali ją jako wielonarodowościowy twór bez perspektyw rozwojowych. Było w tym trochę prawdy. Sojusz czechosłowacko-rumuńsko-jugosłowiański miał charakter prowizoryczny i nie gwarantował bezpieczeństwa w strefie naddunajskiej. W momencie osłabienia Francji i wzmocnienia Niemiec i ZSRR stracił rację bytu. Musiała nastąpić degradacja polityczna tego całego regionu europejskiego. Po anschlussie Austrii i Konferencji Monachijskiej cały obszar naddunajski znalazł się w stre-

\footnotetext{
${ }^{16}$ Hodža nie był jedynym politykiem słowackim, który uważał za celowe zjednoczenie państw środkowoeuropejskich. Koncepcje z tego zakresu formułował Karol Sidor, znany ze swych poglądów filopolskich. Planował on utworzenie wspólnoty narodów katolickich na pomoście bałtycko-adriatyckim.

17 Uzasadniał to następująco: „Pod naciskiem wydarzeń politycznych za granicą uznaje się dziś już powszechniej, że właśnie Słowacja tworzy pomost dla geograficznych związków ziem czeskich z Polską i Rumunią i że właściwie Dunaj jest w polityce wynikającej z Małej Ententy i w polityce środkowoeuropejskiej niezbędną bazą geopolityczną dla czechosłowackiej polityki międzynarodowej” (Hodža, 2002b, s. 188).
} 
fie wpływów hitlerowskich Niemiec, a te nie były zainteresowane podmiotowością jego składowych. Podobna sytuacja miała miejsce po zakończeniu wojny, gdy całe to terytorium zostało zwasalizowane przez Związek Sowiecki. Światłe koncepcje Hodžy w ówczesnych uwarunkowaniach politycznych były utopijne i niemożliwe do zrealizowania. Po wielu latach można jednak spojrzeć na nie inaczej, miały bowiem głęboką wymowę symboliczną o wymiarze ponadczasowym. Wskazywały bezspornie, ze istnieje w Europie obszar zamieszkały przez wiele narodów, które przy dogodnych warunkach geopolitycznych mogą teoretycznie stworzyć związek federacyjny wokół wielkiej rzeki stanowiącej oś integracji i współpracy.

\section{Federacja Środkowej Europy}

Wieloletnie przemyślenia na temat potrzeby jedności politycznej Środkowej (Centralnej) Europy, które Hodža wielokrotnie przedstawiał publicznie, zostały opublikowane dwa lata przed jego śmiercią w języku angielskim (Hodža, 1942). Przebywał już wówczas na emigracji w Stanach Zjednoczonych, odsunięty od bieżącej działalności politycznej. Był krytycznie nastawiony do Józefa Tiso, Ferdynanda Durčansky'ego, Aleksandra Macha i innych swoich byłych współtowarzyszy, którzy pod protektoratem Hitlera rządzili w marionetkowym państwie słowackim (Slovenská Republika). Sceptycznie ale lojalnie odnosił się do ekipy Benesza i Jana Masaryka, którzy tworzyli emigracyjny rząd Republiki Czechosłowackiej w Londynie.

Opracowanie Hodžy zostało wydane pod jednoznacznym tytułem: Federation in Central Europe. Reflections and Remiscense. Początkowo wzbudziło pewien rozgłos, ale potem uległo zapomnieniu. Wynikało to z wielorakich przyczyn. Cała Środkowa Europa była wówczas okupowana przez wojska niemieckie, a niebawem miała się znaleźć w sowieckiej strefie wpływów. Przedstawiciele tak małego narodu jak słowacki byli traktowani protekcjonalnie i nie wzbudzali na zachodzie zainteresowania. Koncepcja Hodžy nawołująca do politycznego zjednoczenia i samookreślenia tej peryferyjnie położonej części Europy była dla wielkich tego świata pomysłem wręcz abstrakcyjnym. Ten stan lekceważenia i ignorancji trwał przez kolejne dziesięciolecia powojenne.

Kwestia nowej organizacji krajów środkowoeuropejskich nabrała aktualności dopiero po zmianach geopolitycznych na przełomie lat 1980. i 1990. Po uzyskaniu przez państwa Środkowej Europy podmiotowości i likwidacji imperium sowieckiego problematyka tej części Europy stała się bardziej popularna. Wrócono pamięcią do wydanej przed laty książki. Została on przetłumaczona na niemiecki i opublikowana w Wiedniu pod tytułem Schicksal, Donauraum, Erinnerungen (Hodža, 1995). Nadszedł też odpowiedni czas, aby to opracowanie wydać w ojczystym języku autora. Dokonało się to po 55 latach od angielskiego pierwodruku. Tłumaczenie, poprzedzone kompetentnym wpro- 
wadzeniem Pavola Lukáča, stało się dostępne dla czytelnika słowackiego. We wstępie zawarto genezę opracowania oraz wiele informacji o poglądach Hodžy i jego dokonaniach intelektualnych (Lukáč, 1997). Książka, w której zamieszczono również inne prace autora, stała się impulsem do dyskursu naukowego, w którym podkreślano nowatorstwo i wartość naukową oraz polityczną wydanego przed laty dzieła. Tytuł słowacki jest zbliżony do oryginału angielskiego i brzmi: Federacia v strednej Európe a iné štúdie (Hodža, 1997).

Czytelnik polski ze względu na bliskość językową jest w stanie poznać w pełni osiągnięcia twórcze Hodžy oraz jego zdolności wizjonerskie. Nie ma potrzeby dokładnego prezentowania w tym miejscu obszernych przemyśleń związanych z historią, geografią i dylematami politycznymi państw środkowoeuropejskich, dlatego ograniczono się do zarysowania propozycji realizacyjnych zmierzających do federalizacji i jedności państw środkowoeuropejskich.

Planując przyszłość państw usytuowanych w dorzeczu Dunaju Hodža starał się ograniczyć ich straty ekonomiczne wynikłe z rozpadu wielkiego mocarstwa Habsburgów. Nowa koncepcja integracyjna miała znacznie szerszy zakres terytorialny oraz bardziej uwypuklała kwestie geopolityczne. Ideą przewodnia było utworzenie wielkiej federacji, która mogłaby przeciwstawić się zarówno Niemcom, jak i Rosji. Wymagałoby to zjednoczenia kilkunastu państw położonych miedzy Bałtykiem, Morzem Czarnym i Adriatykiem - zróżnicowanych etnicznie i kulturowo, a nękanych od stuleci konfliktami o dominację i dogodniejsze granice

We wstępnej części opracowania Hodža rozważa kwestie delimitacyjne, zastanawiając się nad rozległością terytorialną tzw. Środkowej Europy. Odnosi się przede wszystkim do projektu tzw. Mitteleuropy, której twórcami ideowymi byli dwaj uczeni niemieccy: związany z Uniwersytetem Wrocławskim geograf Joseph Partsch oraz liberalny ekonomista Friedrich Naumann ${ }^{18}$. Tego ostatniego Hodža osobiście poznał w październiku 1915 r. w Wiedniu i przeprowadził z nim rozmowę na temat przyszłości krajów i prowincji usytuowanych na wschód od Niemiec. Obaj byli zwolennikami zjednoczenia Środkowej Europy, a dzieliło ich przede wszystkim spojrzenie na rolę Niemiec w tym przedsięwzięciu. Naumann uważał, że ze względu na potencjał demograficzny i gospodarczy tylko Niemcy są w stanie przyjąć rolę inicjatora, a następnie hegemona. Jedynie pod kuratelą i przewodnictwem Niemiec cały wielki obszar sięgający od granic właściwej Rosji i Turcji do Adriatyku i Alp może być zjednoczony. Stanowisko Hodžy było odmienne, chociaż nie negował racjonalności w rozumowaniu swego adwersarza, a nawet jego szczerych, dalekich od szowinizmu intencji. Niemniej Hodža obawiał się supremacji niemieckiej. Wszelkie przesłanki obiektywne wskazywały bowiem, że w przypadku włączenia Niemiec kształtująca się wspólnota będzie niezrównoważona, a rola pozo-

\footnotetext{
${ }^{18}$ Szczegółowo o niemieckiej koncepcji Mitteleuropy i udziale Partscha i Naumanna w jej tworzeniu zob. P. Eberhardt (2005).
} 
stałych państw sprowadzona do marginalnej. Przeciwstawiał się tendencjom niemieckiego Drang nach Osten, i to bez względu na formę, w jakiej występowały: światłej i liberalnej koncepcji Naumanna, imperialnej cesarza Wilhelma II, mocarstwowej kanclerza Gustawa Stresemanna, czy rasistowskiej Heinricha Himmlera. Słowacki polityk nie miał złudzeń i dlatego wykluczał udział Niemiec w procesie zjednoczeniowym Środkowej Europy. Dostrzegał również niebezpieczeństwo w istnieniu licznej mniejszości niemieckiej, która mogła być orędownikiem pangermanizmu.

Biorąc powyższe pod uwagę Hodža dzielił Europę na trzy części składowe: zachodnią, do której włączał Niemcy, środkowoeuropejską oraz wschodnią (Rosję). Główny podział determinował pogląd na usytuowanie geograficzne Środkowej Europy. Można przytoczyć jego tezę: „podstawowym elementem integracyjnym są nie Niemcy, ale korytarz: Wisła, przesmyk cieszyńsko-żyliński - rzeka Wah, środkowy Dunaj - serbska Morawa - Wardar - Saloniki” (Hodža, 1997, s. 45; Tauchen, 2009, s. 449). Wokół tej osi geograficznej powinna usytuować się wspólnota środkowoeuropejska miedzy Niemcami, Włochami a Rosją. Propozycja Hodžy była polemiczna wobec poglądów Partscha, który zachodnią granicę Mitteleuropy wytyczał wzdłuż linii łączącej Ostendę z Genewą; Hodža przesuwa ją o kilkaset kilometrów na wschód do ówczesnej granicy polsko-niemieckiej i czesko-niemieckiej. Granicę wschodnią Mitteleuropy Partsch kreśli po linii prostej łączącej Memel (Kłajpedę) z bułgarskim Burgas, według Hodžy zaś cała Polska i Rumunia w granicach międzywojennych należy integralnie do Środkowej Europy (Lukáč, 1997, s. 18). Uzasadnienie przebiegu granicy wschodniej Środkowej Europy według słowackiego działacza nie polega dyskusji: tam gdzie panuje Rosja, mamy do czynienia ze wschodnią Europą. Za tą rubieżą bowiem jest już odrębna cywilizacja, funkcjonuje inny system władzy i odmienna skala wartości. Między tak wyznaczonymi rozgraniczeniami istnieje zagrożona ekspansją z obu stron Środkowa Europa (Hodža, 1997, s. 49). Do zilustrowania tego niebezpiecznego położenia Hodža przywołuje metaforę o dwóch kołach młyńskich, którymi są Niemcy i Rosja, a między nimi znajduje się Środkowa Europa. Jeżeli ona nie stanie się zwarta i silna, to te koła ją zdruzgoczą (Lukáč, 1997, s. 20). ${ }^{19}$

W Rosji (ZSRR) Hodža dostrzega państwo despotyczne i agresywne, które bez względu na ustrój i retorykę jaką się posługuje zmierza do rozszerzenia strefy swych wpływów drogą militarnych podbojów. Zdecydowanie przeciwstawia się panslawizmowi - ideologii modnej w XIX wieku wśród czeskich intelektualistów. Nie ma wątpliwości, że jest to kamuflaż stosowany przez Moskwę, za którym kryją się zamierzenia imperialne. Okazał w tym względzie realizm

${ }^{19}$ Podobną analogię wykorzystał również Stefan Żeromski w powieści Wierna rzeka, pisząc o położeniu Polski miedzy Rosją a Niemcami. Trudno wyrokować, czy Hodža samodzielnie przywołał tę przenośnię, czy też znając język polski przeczytał książkę Żeromskiego i zapamiętał trafną metaforę o zamierzeniach Rosji i Niemiec wobec narodów środkowoeuropejskich. 
i pragmatyzm, głosząc poglądy wypowiadane raczej przez polityków polskich niż czeskich lub słowackich, którzy często skłaniali się do filorosyjskości.

Do państw Środkowej Europy Hodža zalicza: Polskę, Czechosłowację, Austrię, Węgry, Rumunię, Jugosławię, Bułgarię i Grecję (ryc. 1). Nie wyklucza w przyszłości dołączenia Albanii oraz Turcji (Tauchen, 2009, s. 460). Nie przewiduje udziału trzech państw bałtyckich (Litwy, Łotwy, Estonii). Podobnie nie uwzględnia Białorusi i Ukrainy - te narody należą według Hodžy do Wschodu, czyli Rosji. Zakłada, że nie są one w stanie oderwać się od imperium sowieckiego, a cywilizacyjnie też nie pasują do Środkowej Europy. Polskę zawsze ujmuje w granicach wersalsko-ryskich. Pisząc o pozycji poszczególnych państw w przyszłych procesach integracyjnych uwypukla znaczenie Polski, ale decydującą rolę przyznaje państwom Małej Ententy, tj. Czechosłowacji, Rumunii i Jugosławii, a z tych trzech - Czechosłowacji - państwu o wzorcowym systemie ustrojowym, najbardziej nowoczesnemu, które ma wszelkie atrybuty aby być przykładem dla całej federacji środkowoeuropejskiej (Hodža, 1997, s. 51). Uważa, że Czechosłowacja jest w pewnym stopniu modelową miniaturą przyszłej federacji obejmującej osiem państw, zajmującą strategiczną pozycję, a generalną stabilność europejską konstruuje na geopolitycznej osi: Francja-Niemcy-nowa Środkowa Europa (Hodža, 1997, s. 52).

Wiele miejsca poświęca kwestiom konstytucyjnym i prawnym. Zakłada, że projektowana federacja będzie unią równych i wolnych państw i narodów. Występuje przeciwko możliwym tendencjom centralistycznym. Przypomina o sytuacji istniejącej w Czechosłowacji, która miała być federacją dwóch równoprawnych narodów, w praktyce zaś uwydatnił się „centralizm Pragi”. Przestrzega też przed „arystokratyzmem węgierskim” na rzecz ustroju demokratycznego i społeczeństwa obywatelskiego. Uważa, że system prawny nowej federacji powinien zapewnić pełną autonomią terytorialną dla wszystkich narodów. W tych postulatach ujawnia się podejście idealistyczne Hodžy, typowe dla twórcy tworzącego wizjonerski i w dużym stopniu utopijny projekt wspólnotowy.

Poza problematyką terytorialną dużo uwagi poświęca autor praktycznemu działaniu i organizacji przyszłej Federacji Środkowoeuropejskiej. Czynnikiem determinującym funkcjonowanie tak zróżnicowanego superpaństwa będzie opracowanie konstytucji regulującej system prawny. Przewiduje demokratyczny wybór prezydenta Federacji, będącego równocześnie zwierzchnikiem sił zbrojnych. Kierowanie pracami rządu powinno przysługiwać kanclerzowi federalnemu. Uprawnienia ustawodawcze przypadłyby federalnemu kongresowi (parlamentowi), składającemu się z posłów powołanych w demokratycznych wyborach (80-120 parlamentarzystów). Utworzony rząd federalny obejmowałby dziewięć branżowych ministerstw (finansów, planowania, spraw zagranicznych, obrony, łączności, środowiska, gospodarki wodnej, sprawiedli- 


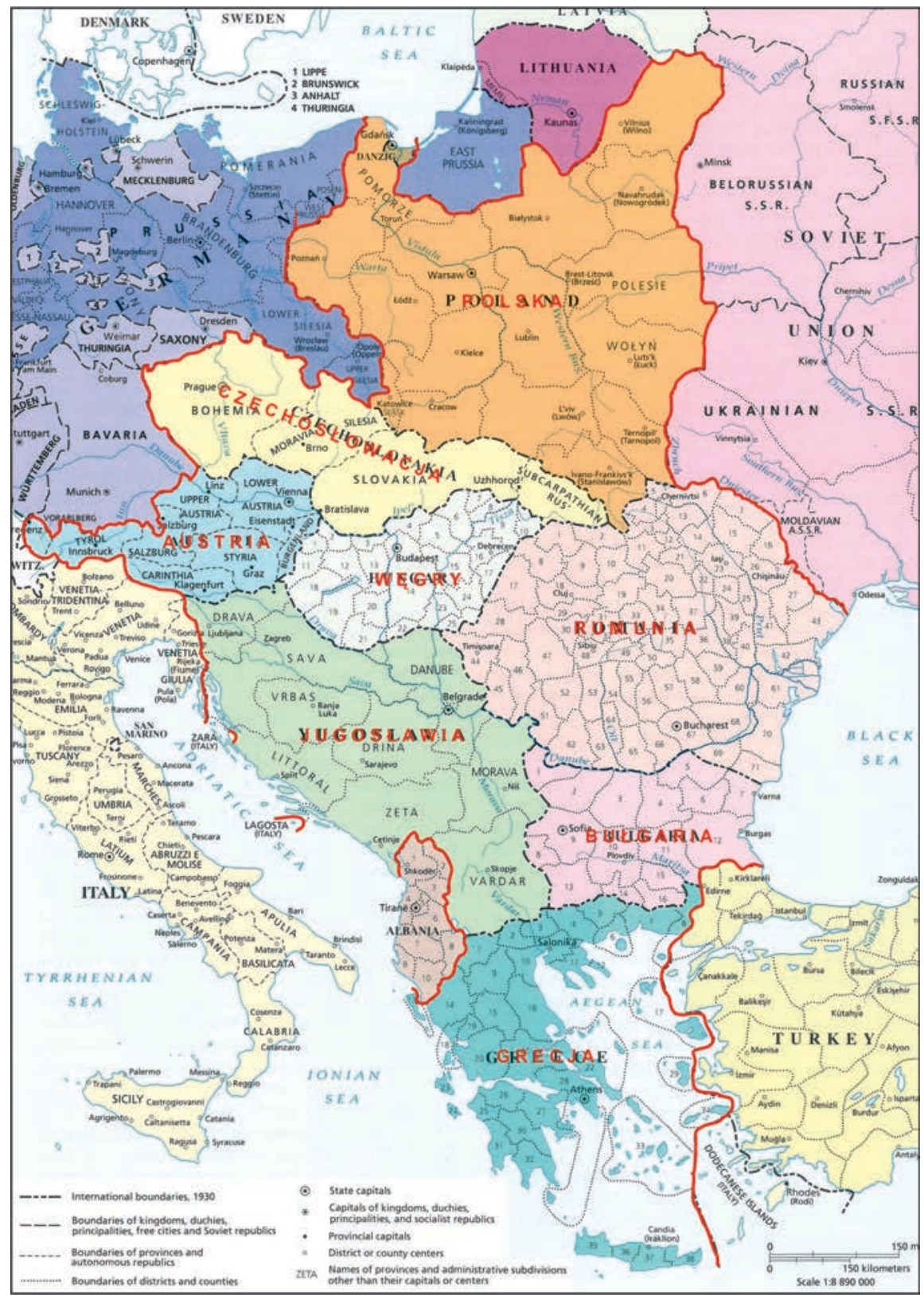

Ryc. 1. Państwa Środkowej Europy według Milana Hodžy Countries of Central Europe according to Milan Hodža Podkład z / Base map from: Historical Atlas of East Central Europe, vol. 1, Paul Robert Magocsi, University of Washington Press, Seattle\& London, s. 150. 
wości i kooperacji). Po zaakceptowaniu konstytucji przez wszystkich sygnatariuszy, bez jej uchylenia, nie byłoby możliwe wystąpienie z federacji. Stanowiłoby to gwarancję stabilności i trwałości ustalonego porządku politycznego (Hodža, 1997, s. 235).

Stanowisko słowackiego polityka wobec wszystkich państw i narodów zamieszkujących Środkową Europę było przychylne i przyjacielskie. Choć krytycznie nastawiony do polityki węgierskiej, naród węgierski obdarzał

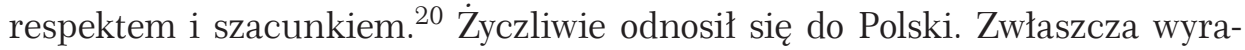
żał to po wrześniu 1939 r. Rozumiał, że upadek Polski oznacza krach wszelkich koncepcji wspólnotowych. Przebywając na emigracji nawiązał ścisły kontakt z polskimi politykami. Pozytywnie odniósł się do wstępnych ustaleń miedzy Sikorskim a Beneszem na temat przyszłej federacji polsko-czechosłowackiej. To porozumienie traktował jako pierwszy krok do jedności bliskich sobie narodów. Nie przewidywał ostrej reakcji sowieckiej i kapitulacji Benesza. Liczył na wsparcie brytyjskie, którego się nie doczekał, ale kierując się tymi złudzeniami nawiązał bliski kontakt z angielskim historykiem Robertem W. Seton Watsonem, który pełnił odpowiedzialne stanowisko w brytyjskim ministerstwie spraw zagranicznych. Za jego pośrednictwem dostarczył rządowi brytyjskiemu memorandum pt. On Collective Security in Central Europe, które stanowi apel do aliantów zachodnich o wsparcie idei zjednoczenia Środkowej Europy.

Próbuje równocześnie spopularyzować opracowaną koncepcję wśród brytyjskiej elity politycznej, publikując artykuł w prestiżowym czasopiśmie angielskim. Reakcja jest jednak odwrotna od spodziewanej. Jego działalność staje się obiektem wyreżyserowanej akcji środowisk prokomunistycznych, nadzorowanych przez dyplomatów sowieckich. Wychodzą artykuły pod hasłem „persona non grata”. W tej kampanii prasowej bierze udział komunista czeski Vladimír Clementis. Dla ekipy Benesza i Masaryka obecność Hodžy w Londynie jest niewygodna i kłopotliwa, gdyż jego krytyczny stosunek do ZSRR jest powszechnie znany ( Lukáč, 2009, s. 32). Jedynym wyjściem satysfakcjonującym jego przeciwników jest jego wyjazd do Stanów Zjednoczonych. Po przyjeździe do tego kraju Hodža nie rezygnuje z działalności na forum publicznym. W wielu wypowiedziach ostrzega przed konsekwencjami utraty podmiotowości politycznej przez państwa środkowoeuropejskie. Przygotowuje na ten temat kolejne memorandum, pt. Europe at the Crossroads, które przekazuje władzom amerykańskim. Nie wzbudza ono jednak większego zainteresowania. Nawiązuje też bliski kontakt z Coudenhove-Kalergim i uzyskuje

${ }^{20}$ Stosunek Hodžy do ludności węgierskiej oddaje wiernie cytat z jego wypowiedzi: „Po rozejściu się z państwem węgierskim pozostała u nas węgierska mniejszość, którą traktujemy nie tylko z szacunkiem, jaki zapewnia jej prawo, ale dzięki własnym doświadczeniom i naturze słowiańskiej traktujemy tę mniejszość zawsze sprawiedliwie, z tym jednak zastrzeżeniem, że nie oddamy ani skrawka ze swojego terytorium i obronimy swój stan posiadania" (Hodža, 2002b, s. 163). 
od niego nominację na przedstawiciela państwa czechosłowackiego w ruchu paneuropejskim Jest to już ostatnia funkcja tego wielkiego słowackiego polityka przed niespodziewaną śmiercią (Múdry, 1949).

\section{Uwagi końcowe}

Liczne były projekty, wizje czy programy, których ostatecznym zamierzeniem było zjednoczenie polityczne całej Europy lub jej poszczególnych części poprzez federalizacje i uformowanie wspólnoty ponadnarodowej. Stopień ich realności był bardzo różny. Powstawały z inicjatywy państw, elit przywódczych, organizacji publicznych i społecznych względnie indywidualnych polityków. Do tych ostatnich należy koncepcja federacji państw Środkowej Europy zaproponowana i opublikowana w 1942 r. przez człowieka, za którym nie stała wówczas żadna siła polityczna, a przeciwnie - swymi poglądami i działalnością narażał się możnym tego świata.

Twórca koncepcji był działaczem politycznym i uczonym pochodzącym z niewielkiego kraju, niemającego tradycji historyczno-państwowych. Motywem jego postępowania był idealizm oraz silna wiara, że federalizm jest jedyną drogą do zapewnienia pokoj i bezpieczeństwo dla kilkunastu narodów narażonych na zniewolenie i degradacje. Obiektem jego fascynacji i troski był obszar w Środkowej Europie pomiędzy Morzem Czarnym, Bałtykiem i Adriatykiem. Na tym rozległym terytorium usytuowanym w strategicznym miejscu kontynentu europejskiego mieszkała ludność o różnym pochodzeniu etnicznym. W rezultacie częstych konfliktów militarnych o przewagę i przebieg rozgraniczeń politycznych zaawansowane były procesy dezintegracyjne. Cały ten obszar był także narażony na podbój ze strony dwóch wielkich mocarstw: Niemiec i Rosji (ZSRR).

Program federacyjny głoszony przez Hodžę powstał w złożonej sytuacji politycznej. Na kontynencie europejskim toczyły się zmagania zbrojne między dwoma zaborczymi i totalitarnymi imperiami, z których każde zamierzało ujarzmić narody środkowoeuropejskie, pozbawiając je podmiotowości politycznej i ustrojowej. Nie było jeszcze wiadomo jak ten konflikt się zakończy. W takich warunkach zaprezentowanie dalekosiężnej koncepcji geopolitycznej wymagało odwagi i inwencji twórczej. Dzięki zdolnościom intelektualnym i erudycji podjęte zadanie zostało pomyślnie zrealizowane: powstała spójna wizja wspólnoty federacyjnej zespołu państw centralnej części Europy. Potrzebę tego przedsięwzięcia uzasadniono argumentami politycznymi, społecznymi i ekonomicznymi. Alternatywą było bowiem włączenie całego analizowanego obszaru w skład hitlerowskich Niemiec względnie stalinowskiego Związku Sowieckiego. Jedynym ratunkiem przed tym realnym scenariuszem, który niestety niebawem się spełnił, było wg Hodžy utworzenie na tyle silnego układu federacyjnego, aby mógł się obronić przed oczekiwaną agresją ze strony zachodniej bądź wschodniej. 
Obecnie z odległej już perspektywy wiemy, że była to koncepcja utopijna, niemożliwa wówczas do zrealizowania. Opanowanie całej Środkowej Europy przez Związek Sowiecki było już przesądzone i tak się niebawem stało. Nie oznacza to jednak, że przemyślenia słowackiego wizjonera nie mają dziś wartości merytorycznej i symbolicznej. Po wielu latach mogą stanowić inspirację do konkretnych zamierzeń o charakterze unifikacyjnym i federacyjnym. Pomijając kwestię realności koncepcja Hodžy ma duże znaczenie teoretyczne, gdyż nie tylko zaproponował scenariusz dochodzenia do jedności, lecz również opracował podstawy konstytucyjno-ustrojowe i zasady funkcjonowania dużego, złożonego związku federacyjnego. Przypominają one w ogólnym zarysie założenia, które po II wojnie światowej przyjęli twórcy jedności zachodnioeuropejskiej: Jean Monet, Robert Schumann oraz Konrad Adenauer. Hodža podobnie jak twórcy wspólnoty europejskiej ujmował ujednolicenie systemu prawnego, wspólną politykę finansową, ograniczenia, a następnie likwidację wewnętrznych ceł, wprowadzenie preferencji handlowych, usprawnienie łączności i komunikacji itp. (Tauchen, 2009, s. 452).

Wiele lat po śmierci Hodžy jego spójny projekt wspólnoty państw środkowoeuropejskich znalazł swój odpowiednik ideowy, chociaż nie geograficzny. Integracja ta nastąpiła w znacznie szerszej skali terytorialnej niż to przewidywał polityk słowacki. Wizja jedności ponad podziałami narodowościowymi, religijnymi i społeczno-ekonomicznymi została zrealizowana.

Istniejąca już od kilku dziesięcioleci Unia Europejska zgodnie z zaleceniami Hodžy jest wspólnotą wielu państw. Nie przewidywał on tylko, że nastąpi najpierw zjednoczenie państw zachodnioeuropejskich, a dopiero potem stowarzyszenie obejmie Środkową Europę. Nie przypuszczał również, że układ federacyjny zamiast południkowo - od Polski do Grecji będzie się rozciągał równoleżnikowo - od Portugalii po Słowację, Polskę, Estonię i Grecję. Poza związkiem federacyjnym pozostał „Wschód”, który Hodža zawsze odróżniał cywilizacyjnie i kulturowo od Środkowej Europy. Obawiał się o bezpieczeństwo narodów środkowoeuropejskich, które zostało dopiero wiele lat później w pełni zapewnione. Przewidywał, że poprzez szerszą integrację Środkowa Europa przestanie być areną stałych wewnętrznych konfliktów zbrojnych, a tendencje odśrodkowe zostaną wyeliminowane na rzecz współpracy i dobrosąsiedztwa. Zostało to również urzeczywistnione dzięki Unii Europejskiej. Wychodząc z tych przesłanek, można uznać słowackiego myśliciela za jednego z wybitnych animatorów i wizjonerów, „ojców duchowych” współczesnej zjednoczonej Europy. 


\section{Piśmiennictwo / References}

Bakker E., 1997, Minority Conflicts in Slovakia and Hungary?, Labirynt Publications, Haag. Borkowski P.J., 2006, Federalizm a budowanie jedności Europy, Studia Europejskie, 2, s. 87-109, Warszawa.

Cambel S., 2001, Štátník a národohospodár Milan Hodža 1878-1944, Veda SAV, Bratislava.

Durica M.S., 2003, Dejiny Slovenska a Slovákov, Vydavatelstvo Lúč, Bratislava.

Eberhardt P., 2005, Geneza niemieckiej koncepcji „Mitteleuropy”, Przegląd Geograficzny, 77, 1, s. 463-481.

Eberhardt P., 2007, Koncepcja „Paneuropy” Richarda N. Coudenhove-Kalergiego, Przegląd Geograficzny, 79, 3-4, s. 439-460.

Eberhardt P., 2010, Polscy prekursorzy idei zjednoczenia politycznego Europy, Przegląd Geograficzny, 82, 4, s. 509-529.

Federalizm. Teorie i koncepcje, 1998, red. W. Bokajło, Wydawnictwo Uniwersytetu Wrocławskiego, Wrocław.

Giza A., 2000, Stowacki ruch narodowy w XIX wieku (do 1914 roku), Wydawnictwo Uniwersytetu Szczecińskiego, Szczecin.

Grabowiec P., 1998, Od partykularyzmu do uniwersalizmu. Polskie koncepcje międzynarodowej integracji politycznej w latach 1939-1945. Zarys problematyki, [w:] Federalizm. Teorie i koncepcje, red. W. Bokajło, Wydawnictwo Uniwersytetu Wrocławskiego, Wrocław, s. 267-308.

Grygajtis K., 2001, Polskie idee federacyjne $i$ ich realizacja w XIX $i$ XX w., Wydawnictwo Wyższej Szkoły Pedagogicznej, Częstochowa.

Hodža M., 1942, Federation in Central Europe, Jarrolds Publisher, London.

Hodža M., 1995, Schicksal Donauraum Erinnerungen, Amaltea-Verlag, Wien.

Hodža M., 1997, Federácia v strednej Európe, Kalligram, Bratislava.

Hodža M., 2002a, Nie centralizm, nie autonomizm, ale regionalizm $w$ jednolitym narodzie politycznym, [w:] Kwestia stowacka w XX wieku, red. R. Chmel, Wydawnictwo GREG, Gliwice, s. 183-188.

Hodža M., 2002b, Odczyt z 10 grudnia 1933 w Bańskiej Bystrzycy, [w:] Kwestia stowacka w XX wieku, red. R. Chmel, Wydawnictwo GREG, Gliwice, s. 161-164.

Johnson O.V., 1985, Slovakia 1918-1938. Education and the Making of a Nation, Columbia University Press, New York.

Juriček J., 1994, Milan Hodža. Kapitola z dejín slovenskej, československej a európskej politiky, Stimul, Bratislava.

Kinsky F., 1999, Federalizm. Model europejski, Wydawnictwo WAM, Kraków.

Kościelak L., 2010, Historia Stowacji, Zakład Narodowy im. Ossolińskich, Wrocław.

Kwestia stowacka w XX wieku, 2002, red. R. Chmel, Wydawnictwo GREG, Gliwice.

Lukáč P., 1997, Stredoeurópanstvo Milana Hodžy, [w:] Milan Hodža. Federácia v strednej Európe a inè štúdie, Kalligram, Bratislava, s. 11-36.

Matusik D., 2009, Koncepcje federacji europejskiej a europejskie procesy integracji, Wydawnictwo Uniwersytetu Śląskiego, Katowice.

Mikulicz S., 1971, Prometeizm w polityce II Rzeczypospolitej, Książka i Wiedza, Warszawa.

Múdry M., 1949, Milan Hodža v Amerike, Geringer Press, Chicago.

Pekník M. (red.), 2006, Milan Hodža a integrácia strednej Európy, Ústav politických vied $\mathrm{SAV}$, Bratislava.

Suchecki W., 1968, Teoria federalizmu, Państwowe Wydawnictwo Naukowe, Warszawa.

Špiesz A., 1992, Dejiny Slovenska a Slovákov, Vydavatelstvo Perfekt, Bratislava. 
Tauchen J., 2009, Milan Hodža a jeho koncepce středoevropské integrace, [w:] Interakce českého a europského práva, Masarykova univerzita, Brno, s. 436-462.

Votočková-Lauermannová O., 1938, Dr. Milan Hodža. Stručný přehled života a dila, Pražská akciová tiskárna, Praha.

Wolański M.S., 1998, Federalizm w myśli politycznej polskich ugrupowań emigracyjnych po II wojnie światowej, [w:] Federalizm. Teorie i koncepcje, red. W. Bokajło, Wydawnictwo Uniwersytetu Wrocławskiego, Wrocław, s. 267-308.

[Wpłynęło: luty; poprawiono: maj 2016 r.]

\section{PIOTR EBERHARDT}

\section{THE FEDERAL CONCEPTS OF MILAN HODŽA}

The article presents the biography and creative achievements of Milan Hodža (18781944), who was an outstanding Slovak politician and scholar of the first half of the 20th century. An active promoter of political union between Central European countries, Hodža was convinced that more than a dozen nations in territory between the Baltic, Black and Adriatic Seas ought to form a close political federation. Given its major demographic and economic potential, a union of this kind was envisaged as strong enough in military terms to be able to defend itself against potential aggression on the part of both Russia (the USSR) and Germany.

In its introductory part, this article considers general issues relating to the understanding of the notions of federation and federationism. In this context, various kinds of federal associations, grouping smaller or larger numbers of relatively autonomous units, are identified. Exemplified by the Unions between the Kingdom of Poland and the Grand Duchy of Lithuania, these functioned in various historical periods, experiencing both success and failure.

The main body of the article is devoted to a description of Milan Hodža's political achievements and scholarly work. He was among the creators of the Czechoslovak state, supporting the federation of the Slovak and Czech peoples within a single political entity. He took high ministerial positions in the central administration in Prague, there defending the interests of the Slovak nation consistently. At the same time, he advanced his aforementioned postulate regarding the establishment of a federation of states situated along the Danube. He included Austria, Czechoslovakia, Hungary, Yugoslavia, Romania and Bulgaria in this group of countries, with the proposed federal association seeking to replace the so-called Small Entente, intended to be directed against the potential threat posed by Hungarian revanchism.

After the Munich Dictate, Milan Hodža was forced to emigrate, staying in France, Britain, and then in the United States. Two years before his death (in 1942), Hodža published an English-language work entitled "Federation in Central Europe", in which he sought to justify the establishment of a federation of countries of Central Europe. He assumed that the association, or union, of free nations and equal states, ought to encompass Poland, Czechoslovakia, Austria, Hungary, Romania, Yugoslavia, Bulgaria, and Greece. In formulating this concept, Hodža opposed the German idea of Mitteleuropa, 
which he saw as aimed at the subordination of Central European nations under German hegemony.

Side by side with the territorial aspect, Hodža devoted ample space in his study to the organisation of the future federation, and especially to systemic and legal aspects, and the potential regulation of internal relations, as well as foreign policies. Hodža also dealt in this study with prerequisites for the federation's future constitution, as well as the competences of the autonomous provinces. The article also describes and comments on these considerations.

The final part of the article seeks to emphasise how entirely unrealistic the idea forwarded by Hodža was, in the geopolitical conditions then existing. The area of Central Europe concerned soon fell within the Soviet zone of influence, and the region's states largely lost their political sovereignty. Yet the vision formulated by Hodža, of political union within Central Europe, was in fact to be implemented to a great extent half a century later. The majority of countries in the region became Member States of the European Union, as a federal association of many nations and states, in principle enjoying equal rights. 